\title{
FORMATION OF SUSTAINABLE DEVELOPMENT REPORTING SOCIAL COMPONENT AS ECONOMIC SECURITY MANAGEMENT ELEMENT
}

\begin{abstract}
This research analyzes the various scientific approaches to accounting which helped establish the absence of the single classification mechanism for social activity objects that are identified as accounting objects, which cause the formation of false, incomparable, incomplete and confusing information for interested users to make their relevant decisions. It suggests the list of accounting objects of enterprise's social activity, which the authors single out at the request of reporting on sustainable development. The process of documenting the social activities is analyzed; the paper determines the areas where it is necessary to improve the existing primary documents. The analytical sections on the accounts of social operations of the company are showed. The article proposes the accounting display of economic operations of social activity as the basic information support of the sustainable development reporting social component formation. The authors introduce the form for the internal report, which aims to summarize the social activity aspects of entities.
\end{abstract}

Keywords: sustainable development; sustainable development reporting; accounting objects; social activities; accounting display.

Settlement of the problem. There is no list of the above-mentioned expenses as the categories of accounting objects except the first three categories of expenditures connected with employment, expenses for employees' training at the current stage of accounting development on the legislative level. That is why, the accounting of sustainable development reporting concerning a social component requires improvement and solution of the issues about the methodology approach formation that will provide information adequacy, completeness and efficiency in nonfinancial reports of entities.

Analysis of the latest researches. The similar problems were discussed in the works of O.Gerasymenko [4], D.O. Grycyshen [5], I.A. Derun [6], I.V. Zhyglej [7], S.O. Levyc'ka [10], T.Mikulska, G.Michalczuk [1] and others.

Statement of the research. We are analyzing the existing approaches to the solution of the abovementioned problem. For example, O.V. Bedzaj and T.V. Fedchenko [2] pay attention to the influence of social activities and their display in accounting. They also determine the list of social activities and corresponding accounting objects. This became the base for the scientists to build the model of accounting objects within the limits of social oriented business, which includes permanent and casual expenditures and economic income such as goodwill.

According to her dissertation research, O.I. Pacula [180] improved the accounting methodology of enterprise's social expenditures on the base of account system reformation and adding subaccounts to the existing Plan of accounts that will allow to obtain the detailed information about every way of bearing social expenses. Besides, the scientist proposed to isolate from wages the payments to workers included into enterprise's work extra payment fund and other encouraging and compensatory payments and the element defined as «Expenses for Wages Payment» to call «Expenses for Workers' Payment», and according to the mentioned suggestions she determined the shifts to account 66 known as «Calculations for Workers' Payments».

Petrenko S.M. and V.O. Besarabov [12] identify the directions of social responsibility which have a financial tendency and determine their interconnection with financial reporting indices. The scientists state that the majority of company's social activity indices are not showed in financial reporting and this situation does not satisfy information needs of interested users.

Kukoba V.P. studies the aspects of business corporate responsibility [9], and determines the following objects which are subjected to accounting and auditing:

- the property of the enterprise and its structural subdivisions including the data on movement of enterprise's social infrastructure assets;

- socially oriented expenses of the enterprise and its structural subdivisions and efficiency of these expenses;

- payments with creditors, especially concerning socially oriented projects and programs;

- payments with the enterprise's founders (partners) in the part of complete satisfying the enterprise's dividend policy demands.

As for the social reporting issues, K.V. Bezverhyj [3] proposes broadened social report, which includes various aspects of enterprise's socially oriented activity. So, the scientist shows different aspects of entity's positive and negative impact on social relations in interconnection with economic categories.

(C) V.V. Nonik, O.M. Baryshnikova, 2017 
Analyzing the different scientific approaches to accounting it is necessary to claim about the absence of the single classification mechanism for social activity objects, which are identified as accounting objects, causes the formation of false, incomparable, incomplete and confusing information for interested users to make their relevant decisions.

We agree with the conclusions of O.V. Bedzaj and T.V. Fedchenko about the influence of social activities on accounting display of enterprise's activities. However, we consider that the list of accounting objects provided by the scientists is not complete enough, as it does not include all the aspects of the entity's social activities. In addition to its expenses and incomes every enterprise is socially responsible before a certain state, customers (suppliers and buyers) and first and foremost, before its employees. Though the list of social expenses proposed by V.P. Kukoba is a bit wider, but it has no classified and specific pattern.

Analyzing the research of O.I. Pacula we pay special attention to the accounting expenses which have to be added with the list of social expenses according to the sustainable development reporting demands which were systematized in the process of research.

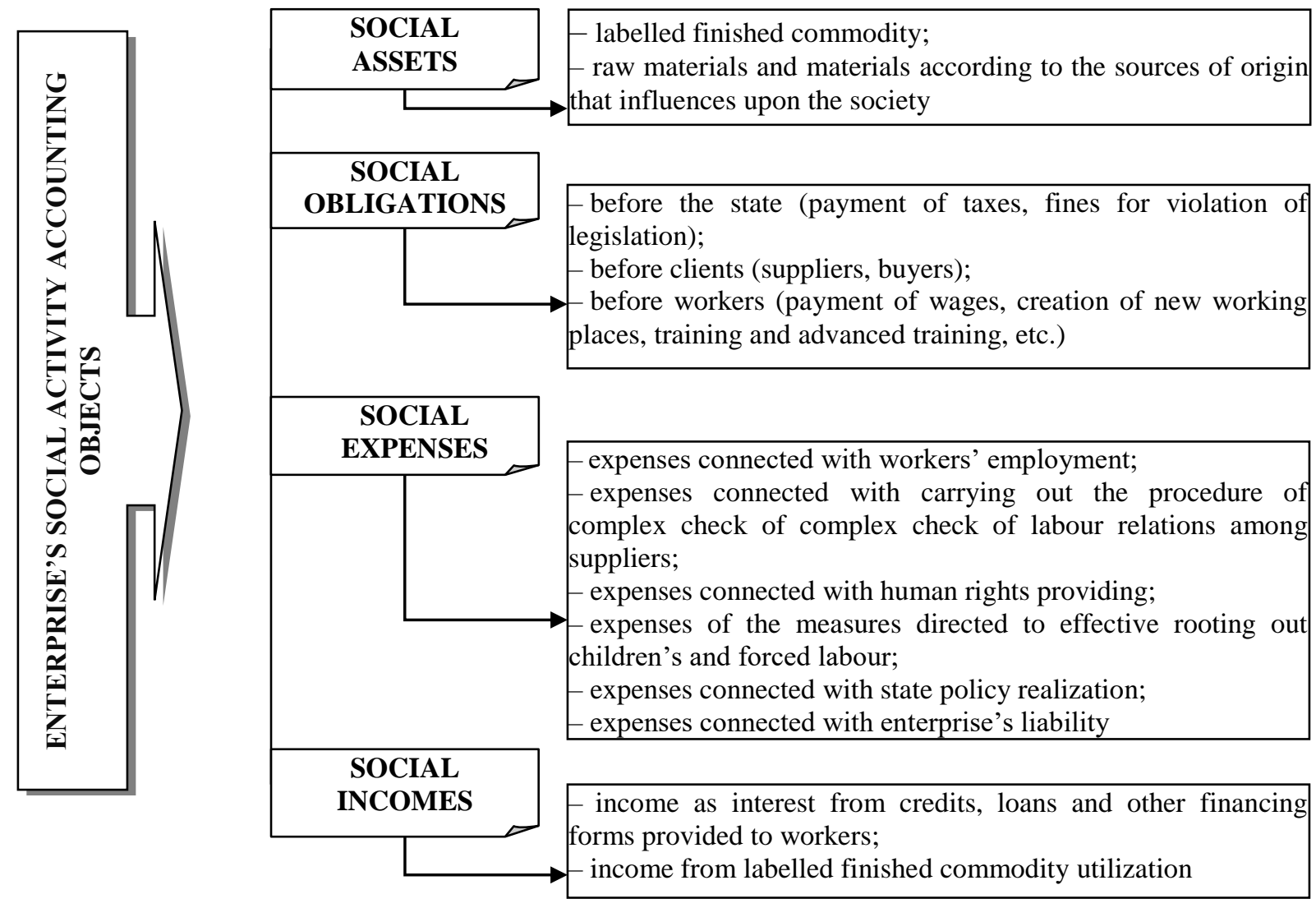

Fig. 1. Enterprise's social activity accounting objects, information about which is showed in sustainable development reporting

So, figure 1 shows the list of enterprise's social activity accounting objects, which are singled out in accordance to the sustainable development reporting demand and on the base of our analysis of scientific sources and nonfinancial reports of entities.

The identified accounting objects characterize how social relations are integrated in enterprise's economic system. The exact determination of the list and essence of every accounting object will influence on the informational content of reporting indices on sustainable development.

Kraevskiy V.N. [8] says that in a narrow meaning, social accounting provides supplying information about labour resources, production and services which are the subject of enterprise's activity that aims to shorten or eliminate amounts of environmental pollution. He considers social accounting in a broad meaning to be the activity displaying the expenses of society related to enterprise's activity.

Considering the offers described above we propose to include the peculiarities in accounting of social activities for enterprise's accounting policy according to the following groups depending on the subcategory of sustainable development accounting indices:

- labour relations: display (of wages charge and payment, timely payment of social taxes) in accounting of enterprise's social obligations; 
- human rights: display of advanced training of workers, preventive treatment, life insurance, etc. in accounting of enterprise's social obligations;

- society: display in accounting of social expenses connected with informing and training labour personnel how to counterwork to corruption, enterprise's employees' participation in election campaigns;

- liability for production: display in accounting of social expenses connected with enterprise's liability in the sphere of providing and using production (providing consumers with information through labelling about positive and negative impact of production on society; obtaining and satisfying claims on breach of consumers' rights).

One of the issues is the necessity to develop the forms of primary documentation and inner reporting that will confirm conducted operations and generalize the results of entity's social activities. That is why the current research analyzes the existing practice of documenting operations with social objects of accounting. It was found out that the current legislation approved the typical forms of primary documents in accounting of wages calculations. As for charge and payment of social taxes, fines and other enterprise's social obligations, the real documenting order of the present operations is acceptable and applied for the operations of social activity.

So, after analyzing the documentation process of social activity objects, we determine the following directions necessary for improving existing primary documents:

1) to include social aspects of relations between enterprise and employees into collective and labour agreements for their further accounting display;

2) to include conditional designation for social activities of enterprise's employees: (the check of labour relations among suppliers; conducting the actions directed to root out children's and forced labour effectively; training enterprise's personnel; training employees at an enterprise; state policy realization) into working time calculation sheet (Standard Form № P-5 adopted by the order of State statistics of Ukraine № 489 of December 5 in 2008);

3) to document expenses connected with enterprise's liability it is reasonable to use (except existing primary documents) the developed calculation card for enterprise's social liability expenses (model 1) which will include a kind of social liability and the calculation of fines if it is needed (if these kinds of recovering payments are applied by an entity not by an authority).

As for the expenses connected with social liability the results of our study make it possible to determine their kinds as:

- expenses concerning accounting falsification, discrimination at a working place, corruption, etc.;

- expenses connected with the measures for decreasing or prevention of negative influence on the society while commodity sale;

- expenses for commodity utilization;

- expenses for commodity labelling;

- expenses for decreasing commodity impact on the society;

- expenses for satisfying claims in money terms and in non-monetary terms.

The suggested form of the primary document allows to systematize and generalize data about the kinds of enterprise's social liability according to the information, which the accounting indices on sustainable development must display.

Nonfinancial reporting in accordance to the accounting data of social activity or social accounting (as scientists define it) widen the borders of traditional accounting and information supply.

Model 1

Developed primary document form «Calculation Card for Enterprise's Social Liability Expenses» Approved by director

(name of institution, organization)

Calculation Card for Enterprise's Social Liability Expenses

in January 2016

\begin{tabular}{|l|l|l|c|c|}
\hline \multirow{2}{*}{$\begin{array}{l}\text { Name of social } \\
\text { liability subject }\end{array}$} & \multicolumn{1}{|c|}{ enterprise on behalf of } & employee & contractor & \multicolumn{1}{c|}{$\begin{array}{c}\text { client } \\
\text { (consumer) }\end{array}$} \\
\cline { 2 - 5 } & Director P.P. Petrov & $\begin{array}{l}\text { manager of sale } \\
\text { department } \\
\text { S.S. Stepanov }\end{array}$ & - & - \\
$\begin{array}{l}\text { Reasons for social } \\
\text { liability expenses }\end{array}$ & $\begin{array}{l}\text { receiving the claim for } \\
\text { providing inadequate } \\
\text { information to consumers } \\
\text { about negative production }\end{array}$ & $\begin{array}{l}\text { delayed supply of } \\
\text { finished commodity }\end{array}$ & - & - \\
\hline
\end{tabular}




\begin{tabular}{|c|c|c|c|c|}
\hline & \multicolumn{4}{|c|}{ End of Model 1} \\
\hline & impact on the society & & & \\
\hline $\begin{array}{l}\text { Description of } \\
\text { social liability } \\
\text { expenses }\end{array}$ & $\begin{array}{l}\text { expenses for finished } \\
\text { commodity utilization }\end{array}$ & $\begin{array}{l}\text { employee's expenses } \\
\text { in the amount of wages } \\
\text { decrease }\end{array}$ & - & - \\
\hline $\begin{array}{l}\text { Expenses in } \\
\text { money terms }\end{array}$ & 987,32 hrv. & 389,00 hrv. & - & - \\
\hline $\begin{array}{l}\text { Calculation of } \\
\text { fines }\end{array}$ & $\begin{array}{l}\text { claim allowance in the } \\
\text { amount of sold finished } \\
\text { commodity cost according } \\
\text { to cash-memo № } 0000344 \\
\text { of } 23.01 .16 \text {. }\end{array}$ & $\begin{array}{l}2 \% \text { of official rate of } \\
\text { pay }\end{array}$ & - & - \\
\hline $\begin{array}{l}\text { Measures for } \\
\text { social liability } \\
\text { prevention or } \\
\text { avoiding }\end{array}$ & $\begin{array}{l}\text { shift in finished } \\
\text { commodity labelling } \\
\text { mechanism }\end{array}$ & $\begin{array}{l}\text { reprimand to } \\
\text { enterprise's employee } \\
\text { of } 12.01 .16 \text {. }\end{array}$ & - & - \\
\hline
\end{tabular}

Chief Bookkeeper

Director
Family name, name, patronymic

Family name, name, patronymic

The next stage of the research about accounting for reporting on sustainable development in the part of social constituent we dedicate to the analysis of display on accounts enterprise's social activity operations. In particular, table 1 shows the analytical views on accounts of the enterprise's social activity operations.

Table 1

Analytical views of accounts

\begin{tabular}{|c|c|c|}
\hline $\begin{array}{l}\text { Indices of } \\
\text { reports }\end{array}$ & Accounts & $\begin{array}{l}\text { Analytical Views on Accounts of Enterprise's Social Activity } \\
\text { Operations }\end{array}$ \\
\hline 1 & 2 & 3 \\
\hline G4-LA1 & $\begin{array}{l}94 \text { «Other expenses of } \\
\text { operational activity», } \\
97 \text { «Other expenses» }\end{array}$ & 1) according to the kinds of expenses \\
\hline G4-LA2 & $\begin{array}{l}66 \text { «Charges for payments } \\
\text { to employees» }\end{array}$ & $\begin{array}{l}\text { 1) according to the kinds of employment; } \\
\text { 2) according to the essential regions of carrying out the activity; } \\
\text { 3) according to the kinds of payments (life insurance; health } \\
\text { protection; compensation for incapacity to work / disablement; } \\
\text { maternity leave / paternity; pension providing; allotment of } \\
\text { company shares; etc.) }\end{array}$ \\
\hline G4-LA13 & $\begin{array}{l}66 \text { «Charges for payments } \\
\text { to employees» }\end{array}$ & $\begin{array}{l}\text { 1) according to gender (males, females); } \\
\text { 2) according to age category (before } 30 \text { years old, } 30-50 \text { years } \\
\text { old, over } 50 \text { years); } \\
\text { 3) according to occupational category }\end{array}$ \\
\hline G4-LA14 & $\begin{array}{l}63 \text { «Charges with } \\
\text { suppliers and contractors» }\end{array}$ & 1) in the part of estimation of labour relations among suppliers \\
\hline G4-HR1 & $03 \ll$ Contract obligations» & $\begin{array}{l}\text { 1) according to the kinds of investment agreements; } \\
\text { 2) according to the kinds of investment programs; } \\
\text { 3) in the part of amounts and strategic importance }\end{array}$ \\
\hline $\begin{array}{l}\text { G4-HR5, } \\
\text { G4-HR6 }\end{array}$ & $\begin{array}{l}94 \text { «Other expenses of } \\
\text { operational activity», } \\
97 \text { «Other expenses» }\end{array}$ & $\begin{array}{l}\text { 1) according to the kinds of measures directed to root out } \\
\text { children's and forced labour effectively; } \\
\text { 2) according to the kinds of expenses }\end{array}$ \\
\hline \multirow[t]{2}{*}{$\begin{array}{l}\text { G4-HR7, } \\
\text { G4-SO4 }\end{array}$} & $\begin{array}{l}66 \text { «Charges for payments } \\
\text { to employees» }\end{array}$ & $\begin{array}{l}\text { 1) according to employees; } \\
\text { 1.1) according to the kind of enterprise's employees' training }\end{array}$ \\
\hline & $\begin{array}{l}94 \text { «Other expenses of } \\
\text { operational activity», } \\
97 \text { «Other expenses» }\end{array}$ & 1) according to the kind of enterprise's employees' training \\
\hline
\end{tabular}


Continuation of Table 1

\begin{tabular}{|c|c|c|}
\hline 1 & 2 & 3 \\
\hline G4-SO6 & $\begin{array}{l}94 \text { «Other expenses of } \\
\text { operational activity», } \\
97 \text { «Other expenses» }\end{array}$ & $\begin{array}{l}\text { 1) according to sa geographical location (according to } \\
\text { countries); } \\
\text { 2) according to political goals; } \\
\text { 3) according to the direction of providing donations (straight or } \\
\text { indirectly through outside the organizations) }\end{array}$ \\
\hline $\begin{array}{l}\text { G4-SO8, G4- } \\
\text { PR4, G4-PR9 }\end{array}$ & $\begin{array}{l}948 \text { «Accepted fines, } \\
\text { forfeits» }\end{array}$ & $\begin{array}{l}\text { 1) according to the kinds of fines (losses compensated in money } \\
\text { terms and in non-monetary terms, revocation of rights, etc.); } \\
\text { 1.1) according to the kinds of penalty recovery subjects }\end{array}$ \\
\hline \multirow[b]{2}{*}{ G4-SO10 } & $\begin{array}{l}63 \text { «Charges with } \\
\text { suppliers and contractors» }\end{array}$ & $\begin{array}{l}\text { 1) according to supplier's location; } \\
\text { 2) according to the kind of negative influence on the society. }\end{array}$ \\
\hline & $\begin{array}{l}94 \text { «Other expenses of } \\
\text { operational activity», } \\
97 \text { «Other expenses» }\end{array}$ & $\begin{array}{l}\text { 1) according to the kinds of measures about decrease or } \\
\text { prevention of negative influence on the society while } \\
\text { commodity selling }\end{array}$ \\
\hline \multirow[b]{2}{*}{ G4-PR3 } & $20 «$ Production stores» & $\begin{array}{l}\text { 1) according to the sources of obtaining; } \\
\text { 2) according to the kind of influence on the society (positive, } \\
\text { negative) }\end{array}$ \\
\hline & 26 «Finished commodity» & $\begin{array}{l}\text { 1) according to the kind of influence on the society (positive, } \\
\text { negative); } \\
\text { 2) according to the level of safety use; } \\
\text { 3) according to the kind of utilization considering the influence } \\
\text { on the society; } \\
\text { 4) according to the necessity in labelling }\end{array}$ \\
\hline G4-PR8 & $\begin{array}{l}36 \text { «Charges with } \\
\text { domestic buyers», } \\
94 \text { «Other expenses of } \\
\text { operational activity», } \\
97 \text { «Other expenses» }\end{array}$ & $\begin{array}{l}\text { 1) according to the kinds of entities sent their claims; } \\
\text { 2) according to the kinds of expenses to satisfy claims (in } \\
\text { money terms and in non-monetary terms) }\end{array}$ \\
\hline
\end{tabular}

We can observe that, the illustrated views of analytical accounting were caused by the necessity to provide trustworthy and comprehended information about social aspects of business running. The accounts are the base for preparing financial, tax, social, and internal reporting and also for nonfinancial reporting, such as reports on sustainable development, in particular.

So, we consider that it is reasonable to describe economic operations and their display in the accounting system including the obtained scientific study results.

Let us pay attention to the social assets as labelled finished commodity, providing services, raw materials and materials according to the sources of origin, that influence upon the society. Account 20 «Production stores» and 26 «Finished Commodity» are used in bookkeeping where corresponding analytical accounts are opened according to the current synthetical ones.

Synthetical accounting of social obligations is conducted on account 65 «Charges for insurance» and 66 «Charges for payments to employees», synthetical accounting of social expenses is conducted on account 94 «Other expenses of operational activity».

Social incomes in accounting are not singled out, but are displayed as a part of cumulative incomes of the activity according to their kinds considering the types of enterprise's activity.

According to the identified and suggested social activity accounting objects it is reasonable to examine their accounting display on the synthetical and analytical accounts.

Table 2 illustrates the accounting display of economic operations in social activity that is studied as the principal information provision of formation of indices of social component in accounting on sustainable development.

Table 2

Accounting Display of Economic Operations in Social Activity: Information Provision of Accounting on Sustainable Development

\begin{tabular}{|c|c|c|c|}
\hline \multirow{2}{*}{$№$} & \multirow{2}{*}{$\begin{array}{c}\text { Contents of economic } \\
\text { operations }\end{array}$} & Debit & Credit \\
\cline { 3 - 4 } & 2 & 3 & 4 \\
\hline 1 & 2 & 23 «Production» & 209.1 «Materials for commodity \\
\hline 1. & Commodity performed labeling & &
\end{tabular}




\begin{tabular}{|c|c|c|c|}
\hline & & & End of Table 2 \\
\hline \multirow[t]{2}{*}{1} & 2 & 3 & 4 \\
\hline & was performed & & labeling» \\
\hline 2. & $\begin{array}{l}\text { Labelled finished commodity } \\
\text { was received at the storehouse }\end{array}$ & $\begin{array}{l}26.2 \text { «Labelled finished } \\
\text { commodity» }\end{array}$ & 23 «Production» \\
\hline \multirow{2}{*}{3.} & \multirow{2}{*}{$\begin{array}{l}\text { Wages for sale department } \\
\text { employees working full time } \\
\text { were charged }\end{array}$} & \multirow{2}{*}{$\begin{array}{l}93.1 \ll \text { Expenses for wages } \\
\text { of sale department } \\
\text { employees working full } \\
\text { time» }\end{array}$} & $\begin{array}{l}66.1 \text { «Charges for payments to } \\
\text { employees working full time» }\end{array}$ \\
\hline & & & 65 «Charges for insurance» \\
\hline \multirow{2}{*}{4.} & \multirow{2}{*}{$\begin{array}{l}\text { Wages for sale department } \\
\text { employees working temporarily } \\
\text { were charged }\end{array}$} & \multirow{2}{*}{$\begin{array}{l}93.2 \ll \text { Expenses for wages } \\
\text { of sale department } \\
\text { employees working } \\
\text { temporarily» }\end{array}$} & $\begin{array}{l}66.2 \text { «Charges for payments to } \\
\text { employees working temporarily» }\end{array}$ \\
\hline & & & 65 «Charges for insurance» \\
\hline 5. & $\begin{array}{l}\text { Expenses connected with } \\
\text { accounting employees' training } \\
\text { (through outside organizations) } \\
\text { were accepted }\end{array}$ & $\begin{array}{l}92.3 \text { «Administrative } \\
\text { expenses connected with } \\
\text { employees' training } \\
\text { (advanced training)» }\end{array}$ & $\begin{array}{l}685 \text { «Charges for other operations» } \\
\text { (according to the kind of supplier of } \\
\text { educational services) }\end{array}$ \\
\hline \multirow[t]{2}{*}{6.} & \multirow{2}{*}{$\begin{array}{l}\text { Expenses connected with } \\
\text { accounting employees' training } \\
\text { (at the expenses of the } \\
\text { enterprise) were accepted }\end{array}$} & \multirow{2}{*}{$\begin{array}{l}92.3 \text { «Administrative } \\
\text { expenses connected with } \\
\text { employees' training } \\
\text { (advanced training)» }\end{array}$} & $\begin{array}{l}66.1 .2 \text { «Charges for payments to } \\
\text { employees providing educational } \\
\text { services» }\end{array}$ \\
\hline & & & $65 \ll$ Charges for insurance» \\
\hline 7. & $\begin{array}{l}\text { Expenses for an election } \\
\text { campaign of enterprise's } \\
\text { employees as candidates to } \\
\text { political parties were accepted }\end{array}$ & $\begin{array}{l}92.4 \text { «Administrative } \\
\text { expenses for an election } \\
\text { campaign of enterprise's } \\
\text { employees as candidates to } \\
\text { political parties» }\end{array}$ & $\begin{array}{l}685 \text { «Charges for other operations» } \\
\text { (according to the kind of supplier of } \\
\text { provided services) }\end{array}$ \\
\hline 8. & $\begin{array}{l}\text { Buyers' claim about violation of } \\
\text { consumers' rights (the debt } \\
\text { before a buyer because of } \\
\text { returning low-quality } \\
\text { commodity was displayed) was } \\
\text { obtained }\end{array}$ & $\begin{array}{l}704 \text { «Deduction from } \\
\text { income» }\end{array}$ & $\begin{array}{l}36.2 \text { «Charges with domestic buyers } \\
\text { concerning the claims about violation } \\
\text { of consumers' rights» }\end{array}$ \\
\hline 9. & $\begin{array}{l}\text { Cost of returned finished } \\
\text { commodity (method «сторно») } \\
\text { was corrected }\end{array}$ & $\begin{array}{l}901 \ll \text { Cost of commodity } \\
\text { sold» }\end{array}$ & $26.2 «$ Labelled finished commodity» \\
\hline 10. & $\begin{array}{l}\text { Здійснено Utilization of } \\
\text { labelled finished commodity } \\
\text { (about which consumers sent } \\
\text { their claim) was performed }\end{array}$ & $\begin{array}{l}946 \text { «Losses from } \\
\text { depreciation of stores» }\end{array}$ & 26.2 «Labelled finished commodity» \\
\hline
\end{tabular}

The illustrated economic operations display the essence of enterprise's social activity, the information about the operations must be displayed in the reporting on sustainable development. That is why the suggested order of accounting on the synthetical and analytical accounts allows to accumulate and systematize the information about various social aspects of business considering the necessary information views. So, in the process of the current research we improved the methodical supply of accounting display for social activity operations in the part of information base forming for social component in accounting on enterprise's sustainable development.

Next, we are going to analyze account reporting and its role in formation of indices of accounting social component on sustainable development (tbl. 3).

Display of social reporting objects in account reporting: directions for improvement

Table 3

\begin{tabular}{|c|c|l|c|}
\hline $\begin{array}{c}\text { Indices of } \\
\text { reports }\end{array}$ & Accounting objects & Account reporting forms & $\begin{array}{c}\text { Reporting drawbacks and } \\
\text { directions for improvement }\end{array}$ \\
\hline 1 & \multicolumn{1}{|c|}{3} & \multicolumn{1}{c|}{3} & 4 \\
\hline $\begin{array}{l}\text { LA1, SO6, } \\
\text { SO8, PR4, }\end{array}$ & $\begin{array}{l}94 \text { «Other expenses of } \\
\text { operational activity», }\end{array}$ & $\begin{array}{l}\text { Report about financial results } \\
\text { (Report about total income) }\end{array}$ & $\begin{array}{l}\text { Are displayed among total } \\
\text { expenses according to the }\end{array}$ \\
\hline
\end{tabular}




\begin{tabular}{|c|c|c|c|}
\hline & & & End of Table 3 \\
\hline 1 & 2 & 3 & 4 \\
\hline $\begin{array}{l}\text { HR5, HR6, } \\
\text { PR8 }\end{array}$ & 97 «Other expenses» & & \multirow{2}{*}{$\begin{array}{l}\text { kinds of activities, that is why it } \\
\text { is reasonable to show the } \\
\text { information in internal reports }\end{array}$} \\
\hline SO10 & $\begin{array}{l}948 \text { «Accepted fines, } \\
\text { forfeits» }\end{array}$ & $\begin{array}{l}\text { Report about financial results (Report } \\
\text { about total income), Report about the } \\
\text { movement of funds }\end{array}$ & \\
\hline $\begin{array}{l}\text { LA2, LA13, } \\
\text { HR7, SO4 }\end{array}$ & $\begin{array}{l}66 \text { «Charges for } \\
\text { payments to employees» }\end{array}$ & $\begin{array}{l}\text { Balance (Report about financial } \\
\text { condition), Report about the movement } \\
\text { of funds, Report about amounts of a } \\
\text { charged single payment for compulsory } \\
\text { to all state social insurance, 1-SS Report } \\
\text { about labour, 6-SS Report about quantity } \\
\text { of employees, their qualitative } \\
\text { description and occupational training }\end{array}$ & $\begin{array}{l}\text { It is reasonable to single out the } \\
\text { expenses for wages payment in } \\
\text { the part of analytics, which is } \\
\text { included into accounting in } \\
\text { enterprise's internal reporting }\end{array}$ \\
\hline LA14, PR3 & $\begin{array}{l}63 \text { «Charges with } \\
\text { suppliers and } \\
\text { contractors» }\end{array}$ & $\begin{array}{l}\text { Balance (Report about financial } \\
\text { condition), Report about the movement } \\
\text { of funds }\end{array}$ & $\begin{array}{l}\text { It is necessary to form the indices } \\
\text { of internal reporting according to } \\
\text { the suggested parts of analytics }\end{array}$ \\
\hline PR8 & $\begin{array}{l}36 \text { «Charges with } \\
\text { domestic buyers» }\end{array}$ & $\begin{array}{l}\text { Balance (Report about financial } \\
\text { condition), Report about the movement } \\
\text { of funds }\end{array}$ & $\begin{array}{l}\text { To single out the line } 3120 \text { in the } \\
\text { Report about the movement of } \\
\text { funds «Charges for payment of } \\
\text { consumers' claims» }\end{array}$ \\
\hline HR1 & $\begin{array}{l}03 \text { «Contract } \\
\text { obligations» }\end{array}$ & Enterprise's internal reporting & $\begin{array}{l}\text { To provide the display of the } \\
\text { information in internal reports }\end{array}$ \\
\hline
\end{tabular}

Enterprise's financial reporting includes social expenses in the part of charges for wages payment and payments to social actions in the following forms of financial reporting: Balance (Report about financial condition), Report about financial results (Report about total income), Report about the movement of funds. Some kinds of social obligations are also displayed in social and statistical reporting. However, the described directions for reporting improvement and the drawbacks of forming separate indices require conducting the research of internal reporting and providing suggestions about its preparation at an enterprise that carries out the social activity provided for display in reporting on sustainable development.

So, on the base of the account reporting study performed we come to the conclusion that to prepare reporting on sustainable development it is necessary to provide preparation of enterprise's internal (management) reporting which will display the full information to manage the enterprise and make decisions by interested users' groups on the basis of nonfinancial reporting. But it is not reasonable to provide in financial reporting the display of those indices which will overload reports informationally.

Model 2 illustrates the form for internal report, which we propose to make for generalization of social aspects of entities' activities.

The suggested form for internal (management) reporting is necessary to provide information to the group of people responsible for preparation of reporting on sustainable development in the part of enterprise's activity social component. The described offers provide:

- information display about positive and negative aspects of social activities (as they consider both enterprise's investments in human capital and the kinds of claims received from consumers and other clients);

- performance of enterprise's social activity estimation by interested users' groups;

- receiving efficient information and information for a certain period to make relevant decisions by management personnel;

- conducting comparative estimation of carrying out social activity, as reporting is prepared for a for a specific account period in comparison with a similar previous one.

So, in the process of research of accounting supply of reporting social component on sustainable development we have analyzed the social category according to the following subcategories: «Practice of labour relations and worthy labour», «human rights», «Society», «Responsibility for commodity». The authors have developed the algorithm of forming reporting on sustainable development according to accounting data. The article describes the scientific results of studies conducted by domestic and foreign researchers and characterizes the current state of accounting display of operations of enterprise's social activity.

The paper identifies the accounting supply issues (on the basis of the proposed mechanism of forming reporting on sustainable development) and in accordance to them it states the research tasks and gives offers about their solution. In particular, the authors have singed out the kinds of social activity expenses and this helped them identify accounting objects of social activity (social assets, social liabilities, social incomes, social expenses). According to the described accounting objects, the paper analyzes their documenting, display on the synthetical and analytical accounts and in account reporting. It was proposed to use at an enterprise such a primary document as «Calculation Card for Enterprise's Social Liability Expenses», the corresponding analytical views of accounts, The Report about social activity as the form of enterprise's internal reporting. The suggestions of the research allow to form qualitative, trustworthy, and complete information in the reporting on sustainable development considering a social component. 
Approved by director

Form of developed internal reporting about social activity

(name of institution, organization)

Report about social activity in January 2016

\begin{tabular}{|c|c|c|}
\hline Index & Period under review & Previous period \\
\hline 1 & 2 & 3 \\
\hline \multicolumn{3}{|l|}{ Social assets: } \\
\hline Cost of produced labelled commodity & 12650,00 & 2900,00 \\
\hline Total: & 12650,00 & 2900,00 \\
\hline \multicolumn{3}{|l|}{ Social liabilities: } \\
\hline for payments to employees & 23890,00 & 30390,00 \\
\hline for payments to the state & 9459,00 & 12987,00 \\
\hline for payments to clients-consumers & 1200,00 & - \\
\hline for payments to suppliers & - & - \\
\hline Total: & 34549,00 & 43377,00 \\
\hline \multicolumn{3}{|l|}{ Social expenses: } \\
\hline Cost of sold labelled commodity & 20190,00 & 5000,00 \\
\hline Expenses connected with employees' employment & 23890,00 & 30390,00 \\
\hline $\begin{array}{l}\text { Expenses connected with conducting the complex check of labour } \\
\text { relations among suppliers }\end{array}$ & - & 1000,00 \\
\hline Expenses connected with providing human rights & 23000,00 & - \\
\hline $\begin{array}{l}\text { Expenses for the measures directed to root out children's and forced } \\
\text { labour effectively }\end{array}$ & - & - \\
\hline Expenses connected with state policy realization & - & - \\
\hline Expenses connected with enterprise's liability & 9700,00 & 2340,00 \\
\hline \multicolumn{3}{|l|}{ Social incomes: } \\
\hline Incomes from labelled finished commodity utilization & 2000,00 & - \\
\hline $\begin{array}{l}\text { Incomes as interest from the credits, loans and other forms of financing } \\
\text { provided to employees }\end{array}$ & 12000,00 & 12000,00 \\
\hline Total: & 14000,00 & 12000,00 \\
\hline Chief Bookkeeper & \multirow{2}{*}{\multicolumn{2}{|c|}{$\begin{array}{l}\text { Family name, name, patronymic } \\
\text { (signature) } \\
\text { Family name, name, patronymic } \\
\text { (signature) }\end{array}$}} \\
\hline Director & & \\
\hline
\end{tabular}

Conclusions. Depending on the subcategory of indices of reporting on sustainable development the authors have built the analytical accounting provision of enterprise's social activity, proposed the improvement of existing primary documents (collective and labour agreements, working time counting sheets) and the development of Calculation Card for Enterprise's Social Liability Expenses for documenting provision of expenses connected with enterprise's liability. The article deals with the typical economic operations of social activity on synthetical and analytical accounts.

The improvement of reporting as the base of information provision of the process of forming indices of social aspects in accounting on sustainable development took place as the proposed form of internal reporting (The Report about social activity), which is necessary to prepare in order to generalize the social aspects of entities' activities. This allows to estimate social activity about positive and negative influence on the society, labour relations, human rights, and also to get trustworthy and efficient information for forming indices of reporting on sustainable development.

\section{References:}

1. Mikulska T. Raportowanie społecznej odpowiedzialności przedsiębiorstwa / T.Mikulska, G.Michalczuk // Zeszyty Naukowe Uniwersytetu zczecińskiego. Finanse, Rynki Finansowe, Ubezpieczenia. - 2014. - Nr. 69. - S. $209-219$.

2. Бедзай O.B. Соціальна відповідальність бізнесу: проблеми розвитку та бухгалтерського обліку [Електронний ресурс] / O.B. Бедзай, T.B. Федченко // Проблемы материальной культуры. Экономические науки. - Режим доступу : http://dspace.nbuv.gov.ua/xmlui/bitstream/handle/ 123456789/92349/18Bedzai.pdf?sequence $=1$.

3. Безверхий К.В. Звітність про результати соціальної діяльності підприємства / К.В. Безверхий // БІЗНЕСІНФОРМ. - 2015. - № 8. - С. 165-174.

4. Герасименко $O$. Соціальний облік та нефінансова звітність як інструменти реалізації соціальної відповідальності / О.Герасименко // Вісник Київського національного університету імені Тараса Шевченка. Серія : Економіка. - 2012. - № 137. - С. 39-43.

5. Грищишен Д.О. Бухгалтерський облік в системі управління економіко-екологічною безпекою промислових підприємств : монографія / Д.О. Грицишен. - Житомир : ЖДТУ, 2015. - 540 с. 
6. Дерун I.A. Корпоративна соціальна звітність як додаток до фінансової звітності / І.А. Дерун // Вісник Київського національного університету ім. Тараса Шевченка. Серія : Економіка. - 2015. - Вип. № 10 (175). C. $10-16$.

7. Жиглей I.B. Бухгалтерський облік соціально відповідальної діяльності суб'єктів господарювання: необхідність та орієнтири розвитку : монографія / І.В. Жиглей. - Житомир : ЖДТУ, 2010. - 496 с.

8. Краевский B.H. Социальный учет: проблемы и перспективы развития [Электронный ресурс] / В.Н. Краевский. - Режим доступа : http://cyberleninka.ru/article/n/sotsialnyy-uchet-problemy-i-perspektivyrazvitiya.

9. Кукоба В.П. Корпоративна соціальна відповідальність підприємства: аспекти сучасного обліку та аудиту витрат / В.П. Кукоба // Ефективна економіка. - № 8. - 2012. - Режим доступу : http://www.economy.nayka.com.ua/?op=1\&z=1312.

10. Левищька С.О. Соціальна складова підприємницької діяльності як об’єкт обліку / С.О. Левицька // Наукові записки Національного університету «Острозька академія». Серія : Економіка» : зб-к наук. праць ; ред.-кол. : І.Д. Пасічник, O.I. Дем’янчук. - Острог : Вид-во Нац. ун-ту «Острозька академія». - 2014. - Вип. 26. - С. 114-118.

11. Пачула О.І. Облік і контроль соціальних витрат підприємства : автореф. дис. ... канд. екон. наук : 08.00 .09 / О.І. Паиула. - Київ, 2008. - 25 с.

12. Петренко C.M. Формування об'єктів соціально орієнтованого обліку та розкриття інформації про них у фінансовій та соціальній звітності [Електронний ресурс] / C.M. Петренко, В.О. Бесарабов. - Режим доступу : http://irbis-nbuv.gov.ua/cgibin/irbis_nbuv/cgiirbis_64.exe?C21COM=2\&I21DBN=UJRN\&P21DBN=UJRN\&IMAGE_FILE_DOWNLOAD=1\&Image_fi le_name=PDF/vdnuete_2013_4_23.pdf.

\section{References:}

1. Mikulska, T. and Michalczuk, G. (2014), «Raportowanie społecznej odpowiedzialności przedsiębiorstwa», Zeszyty Naukowe Uniwersytetu zczecińskiego, Finanse, Rynki Finansowe, Ubezpieczenia, No. 69, pp. 209-219.

2. Bedzaj, O.V. and Fedchenko, T.V., «Social'na vidpovidal'nist' biznesu: problemy rozvytku ta buhgalters'kogo obliku», Problembl materyal'noj kul'turbl. Эkonomycheskye nauky, available at: http://dspace.nbuv.gov.ua/xmlui/bitstream/handle/ 123456789/92349/18-Bedzai.pdf?sequence=1

3. Bezverhyj, K.V. (2015), «Zvitnist' pro rezul'taty social'noi' dijal'nosti pidpryjemstva», BIZNESINFORM, No. 8, pp. $165-174$.

4. Gerasymenko, O. (2012), «Social'nyj oblik ta nefinansova zvitnist' jak instrumenty realizacii' social'noi' vidpovidal'nosti», Visnyk Kyi'vs'kogo nacional'nogo universytetu imeni Tarasa Shevchenka, Serija Ekonomika, No. 137, pp. 39-43.

5. Grycyshen, D.O. (2015), Buhgalters'kyj oblik v systemi upravlinnja ekonomiko-ekologichnoju bezpekoju promyslovyh pidpryjemstv, monografija, ZhDTU, Zhytomyr, $540 \mathrm{p}$.

6. Derun, I.A. (2015), «Korporatyvna social'na zvitnist' jak dodatok do finansovoi' zvitnosti», Visnyk Kyi'vs'kogo nacional'nogo universytetu im. Tarasa Shevchenka, Serija Ekonomika, Issue No. 10 (175), pp. 10-16.

7. Zhyglej, I.V. (2010), Buhgalters'kyj oblik social'no vidpovidal'noi' dijal'nosti sub’jektiv gospodarjuvannja: neobhidnist' ta orijentyry rozvytku, monografija, ZhDTU, Zhytomyr, $496 \mathrm{p}$.

8. Kraevskij, V.N., «Social'nyj uchet: problemy i perspektivy razvitija», available at: http://cyberleninka.ru/article/n/sotsialnyy-uchet-problemy-i-perspektivy-razvitiya

9. Kukoba, V.P. (2012), «Korporatyvna social'na vidpovidal'nist' pidpryjemstva: aspekty suchasnogo obliku ta audytu vytrat», Efektyvna ekonomika, No. 8, available at: http://www.economy.nayka.com.ua/?op=1\&z=1312

10. Levyc'ka, S.O. (2014), «Social'na skladova pidpryjemnyc'koi' dijal'nosti jak ob'jekt obliku», Naukovi zapysky Nacional'nogo universytetu "Ostroz'ka akademija», Serija Ekonomika, zbirnyk naukovyh prac', in Pasichnyk, I.D. and Dem'janchuk, O.I. (ed.), Vyd-vo Nac. un-tu «Ostroz'ka akademija», Ostrog, Vol. 26, pp. 114-118.

11. Pacula, O.I. (2008), Oblik $i$ kontrol' social'nyh vytrat pidpryjemstva, avtoref. dys. kand. ekon. nauk: 08.00.09, Kyi'v, 25 p.

12. Petrenko, S.M. and Besarabov, V.O. (2013), «Formuvannja ob’jektiv social'no orijentovanogo obliku ta rozkryttja informacii' pro nyh $\mathrm{u}$ finansovij ta social'nij zvitnosti», available at: http://irbis-nbuv.gov.ua/cgibin/irbis_nbuv/cgiirbis_64.exe?C21COM=2\&I21DBN=UJRN\&P21DBN=UJRN\&IMAGE_FILE_DOWNLOAD= 1\&Image_file_name=PDF/vdnuete_2013_4_23.pdf

NONIK Valerii Victorovych - candidate of juridical sciences, vice-president in scientific and pedagogical work, juridical and social matters at Zhytomyr State Technological University.

Scientific interests:

- financial and economic security management.

BARYSHNIKOVA Olena Mykolaivna - candidate of economic sciences, assistant of the department of economic security, public management and administration at Zhytomyr State Technological Universit.

Scientific interests:

- financial and strategic management;

- management of stable development. 